\title{
Are vertical distribution patterns of scleractinian corals maintained by pre- or post-settlement processes? A case study of three contrasting species
}

\author{
Craig Mundy ${ }^{1,2, *}$, Russ Babcock ${ }^{3}$ \\ 'Australian Institute of Marine Science, PMB 3, Towrisville MC, Queensland 4810, Australia \\ ${ }^{2}$ Zoology Department, University of Queensland, Brisbane, Queensland 4072, Australia \\ ${ }^{3}$ Leigh Marine Laboratory, University of Auckland, PO Box 349, Warkworth, New Zealand
}

\begin{abstract}
Vertical zonation of hard corals in tropical coral reef systems is a well documented and predictable pattern in the organisation of tropical coral communities. However, the mechanisms that underly vertical zonation of hard corals are poorly understood. Two alternative conceptual models for the maintenance of vertical zonation are considered; depth-dependent settlement of larvae, or indiscriminant settlement of larvae with distributions determined by differential post-settlement mortality with depth. These alternative models were evaluated by undertaking field translocation experiments using $10 \mathrm{~d}$ old juveniles of 3 species with contrasting adult distributions: Goniastrea aspera (Verrill)restricted to shallow reef flat habitats; Oxypora lacera (Verrill)-restricted to low light, lower slope habitats; and Platygyra daedalea (Ellis and Solander) - a species with a broad depth range. Laboratoryraised larvae of each species were settled onto terracotta settlement plates and the plates translocated to 3 depths in the field: reef flat $(0 \mathrm{~m})$, mid slope $(5 \mathrm{~m})$, lower slope $(10 \mathrm{~m})$. Survival of the laboratorysettled juveniles was monitored at 3,6 and 12 mo after settlement. For each of the 3 species, juveniles survived equally well at all 3 depths over the 12 mo study period. The pattern of survivorship of $G$. aspera and $P$. daedalea among depths, however, was dependent on plate surface (top, bottom). Given the absence of depth-dependent survival of juveniles from the 2 zone-specific species $G$. aspera and $O$. lacera, we reject the hypothesis that adult distribution patterns of these 2 species is determined by indiscriminant settlement of larvae followed by differential early post-settlement mortality with depth.
\end{abstract}

KEY WORDS: Settlement · Early post-settlement mortality · Vertical zonation · Corals

\section{INTRODUCTION}

On tropical coral reefs, vertical zonation represents a major pattern in the organisation of scleractinian coral communities. Differences among species of corals in tolerances to several physical factors (wave energy, currents, desiccation, light, temperature and sedimentation) are thought to determine the upper and/or lower limits of species depth distributions (Done 1982, Sheppard 1982, Sebens \& Done 1992). Biological factors (competition and predation) have also been suggested as important controls on the depth distributions

\footnotetext{
-Present address: School of Zoology, University of Tasmania, GPO Box 252-05, Hobart, Tasmania 7001, Australia.

E-mail: craig.mundy@utas.edu.au
}

of corals (Glynn 1976, Sheppard 1982, Huston 1985, Chadwick 1991), although the widespread importance of biological controls for depth distributions of corals on tropical reefs has yet to be demonstrated. Previous attempts to unravel the processes underlying vertical zonation of tropical corals have focused primarily on factors affecting mature, coral populations (reviewed by Sheppard 1982), and with few exceptions (e.g. Babcock \& Mundy 1996, Mundy \& Babcock 1998) have not examined the role of early life-history processes in maintaining vertical zonation.

Results from several descriptive studies of coral distributions indicate that the depth distribution of corals may be set during the early life-history stages of corals (e.g. settlement, early post-settlement). Bak \& Engel (1979) and Rogers et al. (1984) found that the depth 
distribution of juvenile corals of most species mirrors that of the adult corals, at least in terms of presence/ absence. Moreover, depth-specific recruitment of coral species has been observed during recovery of coral communities from intense Acanthaster planci predation (Colgan 1987). This suggests vertical zonation may be set and maintained through 2 alternative mechanisms; widespread and random settlement of planulae followed by differential early post-settlement mortality with depth, or depth-dependent settlement. However, few studies on zonation of sessile marine invertebrates have been able to demonstrate a causal link between larval behaviour in the water column prior to settlement, depth-dependent settlement and the depth distribution of adult populations in zone-specific species (e.g. Grosberg 1982). Differences in photo-responses of larvae of the polychaete Spirorbis borealis from populations at different depths have also been correlated with the vertical distribution of the 2 populations, and the differences between the populations appear to have a genetic basis (Doyle 1974).

The fact that coral planulae are primitive larvae with limited mobility and no specialised sensory organs (Harrison \& Wallace 1990) suggests dispersal and settlement of coral planulae is a stochastic, passive process. This implies an important role for post-settlement processes. However, coral larvae of some species have been shown to prefer a particular orientation at settlement in response to light (Morse et al. 1988, Babcock \& Mundy 1996). Additionally, competent planulae of some zone-specific coral species are able to recognise shallow and deep reef light regimes, and that light intensity and spectral quality significantly affect settlement density in these species (Mundy \& Babcock 1998). This indicates that settlement preferences of larvae of some zone-specific coral species may be adaptive.

Available data on patterns of post-settlement mortality and settlement of tropical corals with depth are also inconclusive. Patterns of early post-settlement survival of the zone-specific coral species Platygyra sinensis and Oxypora lacera could not explain the depth distribution patterns of adult corals of the 2 study species (Babcock \& Mundy 1996). However, the patterns of settlement density of these species in small field enclosures at deep and shallow sites, while not contradictory, do not support the alternative model that vertical zonation of corals is determined by depth-dependent settlement of larvae.

Here we seek evidence for 1 of 2 alternative conceptual models for the maintenance of vertical zonation: depth-dependent settlement of larvae, or indiscriminant settlement of larvae with distributions determined by differential post-settlement mortality with depth. Specifically, we test whether recently settled juveniles of zone-specific species could survive at depths outside the range inhabited by adult corals. This was quantified by placing $10 \mathrm{~d}$ old corals of 3 species (Goniastrea aspera, Platygyra daedalea, Oxypora lacera) with contrasting depth ranges at 3 depths in the field and monitoring their survival over a 12 mo period. Due to the difficulty in locating recently settled juveniles $(0$ to 3 mo) in the field and the poor taxonomic resolution achievable for those juvenile corals that are found, the field experiments were conducted using laboratoryraised larvae of the target species.

\section{METHODS}

Study species and site description. The study was carried out on the windward slope of the fringing reef at Orpheus Island, central Great Barrier Reef $\left(18^{\circ} 35^{\prime} \mathrm{S}\right.$, $146^{\circ} 29^{\prime} \mathrm{E}$ ), approximately $15 \mathrm{~km}$ offshore from the Queensland coast. The study site was located on North East Reef (NER) near the outer edge of the channel between Orpheus and Pelorus Islands. NER is occasionally exposed to high sedimentation from turbid coastal waters flushed through the channel by tidal currents, with an average visibility of approximately 8 to $10 \mathrm{~m}$. The study site slopes gently from the reef flat to a depth of $10 \mathrm{~m}$, where it drops more steeply to the channel floor. Between 8 and $10 \mathrm{~m}$ a fine layer of sediment covers the natural substratum, with little coral growth below $10 \mathrm{~m}$.

Three species of scleractinian corals with contrasting adult depth distributions were used in this study: Goniastrea aspera, Platygyra daedalea, and Oxypora lacега. G. aspera is a small- to medium-sized massive coral and is abundant on the reef flat (Babcock 1984, 1991) but rare or absent on the reef slope. $P$. daedalea is a massive brain coral and is common over a wide range of depths, including the reef flat and lower slope (Miller 1994). O. lacera forms large thin laminar plates (Veron \& Pichon 1980) and is abundant on the lower slope at a depth of $10 \mathrm{~m}$, and rare or absent in shallower depths at this reef. G. aspera and O. lacera were chosen because they have non-overlapping depth ranges, and are dominant species within their respective zones. $P$. daedalea was chosen as a reference species, as the depth range of $P$. daedalea overlaps the depth range of G. aspera and O. lacera, and is common across all depths. All 3 species are broadcast spawning hermaphrodites with similar larval duration and minimum period to settlement competency ( 4 to $5 \mathrm{~d}$, Babcock 1985, Babcock \& Heyward 1986). Differences in adult depth distributions were considered unlikely to be a result of varying reproductive ecology.

Species distribution. To confirm the vertical distribution of the study species at NER, quantitative surveys of Goniastrea aspera, Platygyra daedalea, and Oxy- 
pora lacera abundance were carried out at 3 depths: (1) the reef flat at $0 \mathrm{~m},(2)$ the mid slope at $5 \mathrm{~m}$, and (3) the lower slope at $10 \mathrm{~m}$. Colony abundance was quantified by surveying 10 replicate $20 \mathrm{~m} \times 0.5 \mathrm{~m}$ belt transects at each depth. Each transect was surveyed by laying a $20 \mathrm{~m}$ fibre tape close to the substratum parallel to the reef edge. A colony was counted if the centre of the colony lay within $25 \mathrm{~cm}$ of either side of the tape.

Survival experiments. To obtain larval cultures of each of the 3 study species, 8 to 10 mature colonies of each species were collected on the afternoon of the day of spawning (at Orpheus Island, December 1994) and placed in large plastic containers on the shore. Colonies of the 3 species were kept separately. Approximately 10 to $30 \mathrm{~min}$ after spawning, the eggsperm bundles were collected and transferred to 2.5 l plastic jars and diluted with fresh seawater to reduce sperm concentration. The jars had a large diameter hole in the lid covered with $210 \mu \mathrm{m}$ plankton mesh to allow water exchange. After several hours, the jars containing coral embryos were attached to a rope anchored on the reef slope, where they were maintained for $4 \mathrm{~d}$ to allow development of planulae under ambient temperature and salinity conditions (see Babcock 1985). Fresh seawater was flushed through the jars 2 to 3 times $d^{-1}$.

Competent planulae were settled on plates (terracotta tiles $11 \mathrm{~cm} \times 11 \mathrm{~cm} \times 1 \mathrm{~cm}$ ) that had been conditioned on the reef slope for $10 \mathrm{~d}$ before the experiment. The settlement apparatus consisted of large opaque PVC trays $(400 \mathrm{~mm} \times 270 \mathrm{~mm} \times 150 \mathrm{~mm})$, each of which contained 2 smaller trays with open side panels covered with $210 \mu \mathrm{m}$ plankton mesh. The trays were placed in a large raceway covered with shade cloth and each tray had a continuous supply of fresh seawater. Each inner tray contained a single settlement plate raised $1 \mathrm{~cm}$ above the floor of the tray. Approximately 1500 larvae of one of the 3 species were added to each inner tray. After $5 \mathrm{~d}$ the plates were examined in a water bath using a dissecting microscope and the number of settled planulae on the top and bottom surfaces of the plates were counted. The plates were returned to the aquaria in their original position for a further $4 \mathrm{~d}$ to ensure planulae had completed metamorphosis, and were securely attached before transferring the plates to the field. The mean density of settled corals per plate at each depth at the start of the experiment at NER ranged from 73.0 to 148.6 for Goniastrea aspera, 99.8 to 177.7 for Platygyra daedalea, 121.8 to 201.9 for Oxypora lacera at NER, and 225.9 to 326.7 for O. lacera at Geoffrey Bay (GB).

To examine early post-settlement survival with depth, 10 replicate plates of each species were transferred from the aquaria to the NER study site and placed at each of 3 depths: reef flat $(0 \mathrm{~m})$, mid slope
$(5 \mathrm{~m})$, and lower slope $(10 \mathrm{~m})(10 \times 3 \times 3=90$ plates $)$ The settlement plates were attached to the reef surface using the following method. Small $(100 \mathrm{~mm} \times 50 \mathrm{~mm} \times$ $0.6 \mathrm{~mm}$ ) stainless steel plates with a stainless steel bolt secured to the centre of the plate were anchored to the reef substratum using nylon expansion plugs (Mundy 2000). The nylon expansion plugs were inserted through holes in the stainless steel plate into holes drilled into non-living reef substratum. The settlement plate (which had a hole drilled through the centre) was held to the stainless steel plate with a wing nut, allowing the settlement plate to be easily removed and returned to the same location. The head of the nylon plugs ensured that a gap of $10 \mathrm{~mm}$ was maintained between the bottom surface of the settlement plate and the substratum, providing juveniles with a similar range of conditions to those experienced by larvae settling on natural substrata.

All plates were retrieved in March (3 mo post-settlement) and again in June 1995 (6 mo post-settlement) to quantify survivorship. On these occasions, settlement plates were placed in plastic bins under water, and lifted into a small boat. The plates were then taken back to the Orpheus Island Research Station, where they were kept in an outdoor aquarium with flowthrough unfiltered seawater. Between 6 and 10 replicate plates were retrieved for each species at each depth after $3 \mathrm{mo}$. Plates from the reef flat were kept in full sunlight, whereas plates from the mid and lower slope were shaded with a single and double layer of $50 \%$ shade cloth, respectively. Settlement plates were placed in a water bath and examined microscopically, recording maximum and minimum diameter of all surviving corals on upper and lower plate surfaces. During the 3 and 6 mo census, the plates were returned to the reef within $24 \mathrm{~h}$ of initial collection, and placed in their original location and orientation. The experiment was terminated after $12 \mathrm{mo}$, and the plates bleached overnight in a chlorine solution. The plates were then rinsed in fresh water, dried and examined microscopically for corals. Skeletons of juveniles alive at the time the experiment was terminated were easily distinguished by the clean, white nature of the corallite walls. Skeletons of dead juveniles were usually stained green, coated with a dull white residue, or showed clear evidence of overgrowth by coralline algae, bryozoans, ascidians, polychaetes, or oysters (Wallace \& Bull 1981).

A similar experiment was carried out with Oxypora lacera at an additional site in GB, Magnetic Island during the same period. This experiment was terminated after $3 \mathrm{mo}$, and the settlement plates were transferred to the laboratory at the Australian Institute of Marine Science and held in flow-through aquaria. The plates were examined in the same manner as those from NER. 
The GB site differs from the NER site in that it has a broad reef flat, which slopes gently to a maximum depth of $7 \mathrm{~m}$, and is shallower, less exposed, and more turbid than NER due to its closer proximity to the Queensland coast (Larcombe et al. 1995). The maximum depth of coral growth at GB is approximately 6 to $7 \mathrm{~m}$. Plates with $10 \mathrm{~d}$ old juveniles of Oxypora lacera were attached to the substratum at 2 depths, the reef flat $(0 \mathrm{~m})$ and the lower slope $(6 \mathrm{~m})$, with the same method used at NER. The mean density of juveniles per plate at the start of the experiment ranged between 225.9 and 326.7 at $G B$, with 11 replicate plates retrieved from the reef flat site and 9 replicate plates retrieved from the lower slope.

Data analysis. Survival of the 3 species at NER and Oxypora lacera from GB was examined separately using a 2-factor split-plot ANOVA. The main effects were 'Depth' with 3 levels (reef flat, mid slope and lower slope), 'Surface' with 2 levels (top surface and bottom surface), and 'Plate nested within Depth'. At GB there were only 2 depths, reef flat and lower slope. This design allowed testing for the significance of (a) differences in survivorship among depths, (b) difference in survivorship between plate surfaces, and (c) the presence of a Depth $\times$ Surface interaction. An assumption was made on biological grounds that no interaction was present between Plates (blocking factor) and Plate Surface (Winer et al. 1991). Analyses were carried out on (1) survival from zero to $3 \mathrm{mo}$, (2) survival from zero to $6 \mathrm{mo}$, and (3) survival from zero to $12 \mathrm{mo}$.

As the density of juveniles at the start of the experiment varied 2-fold, it was important to determine if survival was influenced by the initial density of juveniles (i.e. density-dependent survival). To achieve this, Pearson's correlation coefficients were calculated between initial settlement and percent survival to $3 \mathrm{mo}$, between the number of survivors at 3 mo and number of survivors at $6 \mathrm{mo}$, and between the number of survivors at 6 mo and those remaining at 12 mo. Data used in these analyses were total number of survivors per plate surface (depths pooled) for each species.

\section{RESULTS}

\section{Depth range of established corals at NER}

The field surveys at NER confirmed that established populations of Goniastrea aspera, Platygyra daedalea, and Oxypora lacera had contrasting patterns of abundance with depth. $G$. aspera was abundant on the reef flat $(0 \mathrm{~m})$, uncommon on the mid slope $(5 \mathrm{~m})$ and was not recorded within transects or observed in areas adjacent to the transects on the lower slope $(10 \mathrm{~m})$

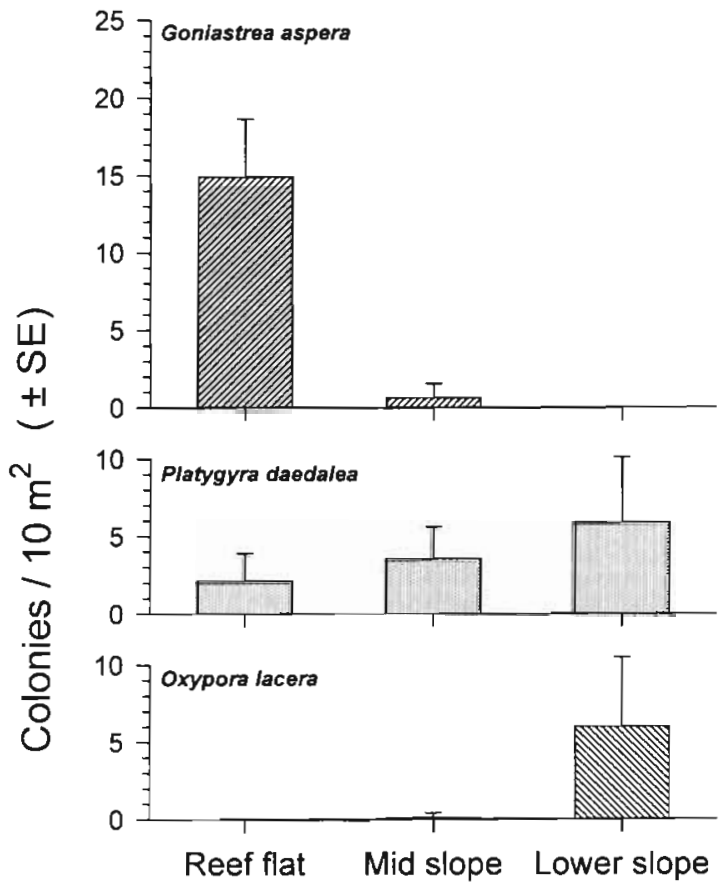

Fig. 1. Mean density of established colonies of Goniastrea aspera, Platygyra daedalea, and Oxypora lacera on the reef flat $(0 \mathrm{~m})$, mid slope $(5 \mathrm{~m})$ and the lower slope $(10 \mathrm{~m})$ at North East Reef, Orpheus Island

(Fig. 1). The reverse pattern was found for O. lacera, which was abundant on the lower slope, rare on the mid slope and was not recorded in transects or observed adjacent to the transects on the reef flat (Fig. 1). P. daedalea was recorded at all depths, with abundance increasing with increasing depth (Fig. 1).

\section{Early post-settlement survival}

Laboratory-settled juveniles of all 3 species survived at all 3 depths through to the end of the experiment at 12 mo. This result was surprising, particularly for the 2 zone-specific species, Goniastrea aspera and Oxypora lacera, for which high mortality of laboratory settled juveniles placed outside the normal depth range of these species was expected. For example, mean survivorship of juvenile $G$. aspera (a shallow water species) after $12 \mathrm{mo}$ at the lower slope site $(3,13)$ was comparable to mean survivorship of this species at the shallow reef flat site (1.36) (Fig. 2a). Similarly, mean survivorship of juvenile $O$. lacera (a deep water/low light species) at the reef flat site (1.18) was equal to mean survivorship of this species at the lower slope site (1.72) (Fig. 2a). Mean survivorship of juvenile Platygyra daedalea also varied little among depths (Fig. 2a) which, in contrast to $G$. aspera and $O$. lacera, is consistent with the depth distribution of established $P$. 


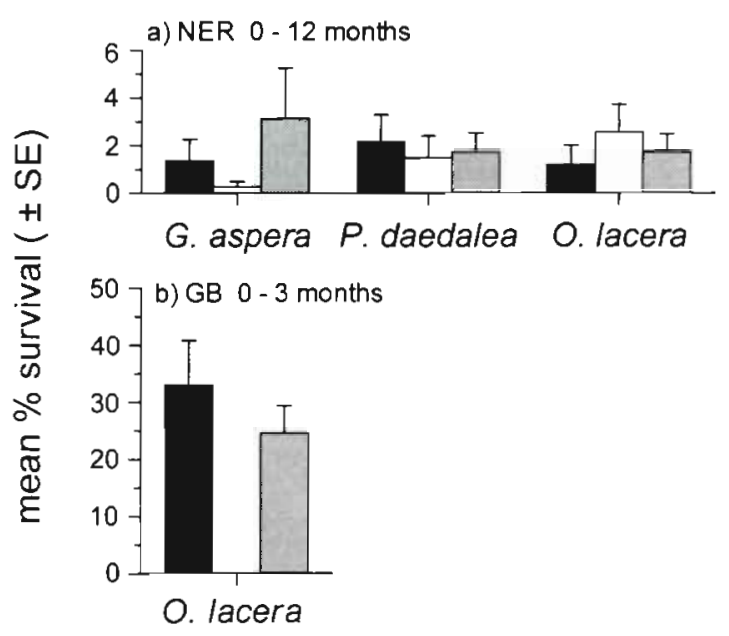

Fig. 2. (a) Mean percent survival of translocated laboratory settled juveniles at North East Reef (NER) from 0 to 12 mo (plate surfaces pooled). (b) Mean percent survival of Oxypora lacera from 0 to 3 mo at Geoffrey Bay (GB) (plate surfaces pooled) . Reef flat $=$ solid bars, mid slope $=$ open bars, lower slope $=$ grey bars

daedalea (Fig. 1). At GB, mean survival of laboratory settled juvenile $O$. lacera after 3 mo was also similar among depths, with juveniles of the lower slope coral $O$. lacera clearly able to survive the relatively harsh conditions of the reef flat site (Fig. 2b).

Mortality of laboratory-settled juveniles (plate surfaces pooled) of all species was greatest during the initial 3 mo period. After 3 mo, less than $15 \%$ of juveniles of all species remained alive at any depth (Fig. 3a). Survival of juveniles from 3 to 6 mo (Fig. 3b), and from 6 to 12 mo (Fig. 3c) after settlement was considerably higher, but variable with few consistent trends among time periods or anong depths. One exception to this was that mean survival of juvenile Goniastrea aspera during the latter time periods was 20 to $30 \%$ higher at the lower slope site than at shallower depths. Only during the last period, 6 to $12 \mathrm{mo}$, was there any evidence of depth-dependent survival. Mean survivorship of Oxypora lacera increased with increasing depth dur- a) NER $0-3$ months
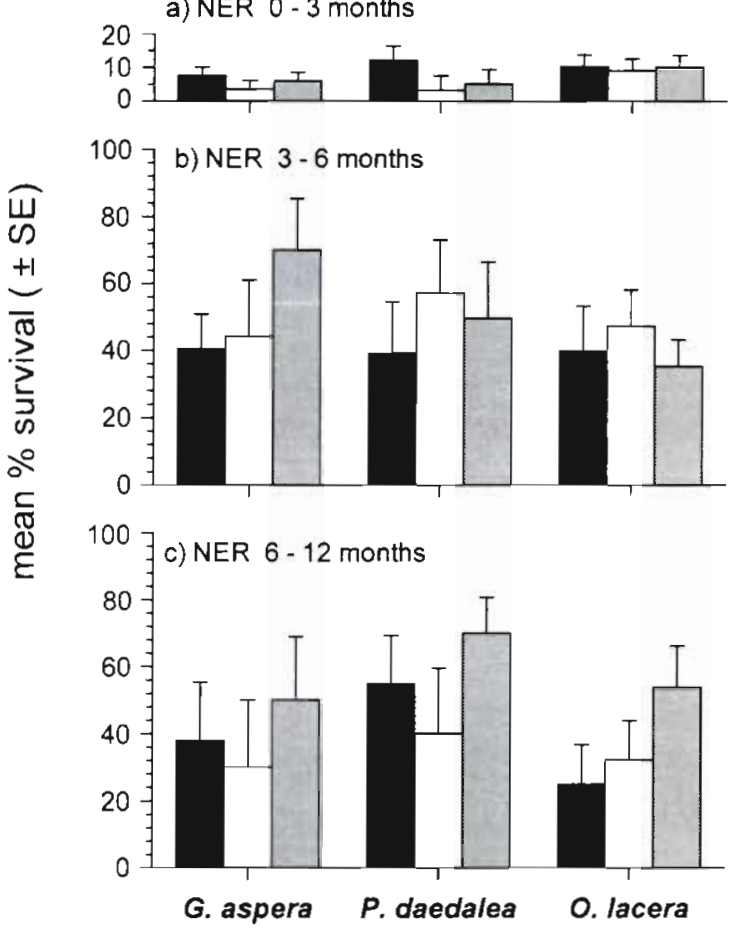

Fig. 3. Mean percent survival of translocated laboratory settled juveniles at NER from (a) 0 to $3 \mathrm{mo}$, (b) 3 to $6 \mathrm{mo}$, (c) 6 to 12 mo (plate surfaces pooled). Reef flat = solid bars, mid slope $=$ open bars, lower slope $=$ grey bars

ing this last period, and represents a change in the trend of survival of $O$. lacera juveniles among depths from zero to $3 \mathrm{mo}$ and from 3 to $6 \mathrm{mo}$ (Fig. 3c).

The patterns of survival with depth were more complex, however, when survival on the exposed top surfaces and protected bottom surfaces of plates was considered. Survivorship of the 2 Faviid species Goniastrea aspera and Platygyra daedalea was dependent on depth and plate surface, with a significant interaction between depth and plate surface found at the 3 and 6 mo census (Tables $1 \& 2$ ). For example, on the reef flat $(0 \mathrm{~m})$, survival of laboratory settled juvenile $G$. aspera was higher on the protected bottom surfaces of

Table 1. ANOVA of Goniastrea aspera survival from zero to $3 \mathrm{mo}$, zero to $6 \mathrm{mo}$, and zero to 12 mo at North East Reef. (Probability of significant $F<0.05^{\mathrm{a}} ;<0.01^{\mathrm{b}} ;<0.001^{\mathrm{c}}$ )

\begin{tabular}{|c|c|c|c|c|c|c|c|c|c|}
\hline \multirow[t]{2}{*}{ Source of variation } & \multicolumn{3}{|c|}{$0-3 \mathrm{mo}$} & \multicolumn{3}{|c|}{$0-6 \mathrm{mo}$} & \multicolumn{3}{|c|}{$0-12 \mathrm{mo}$} \\
\hline & $\mathrm{df}$ & MS & $F$ & $d f$ & MS & $F$ & $\mathrm{df}$ & MS & $F$ \\
\hline Depth & 2 & 216.17 & 1.57 & 2 & 57.41 & 2.01 & 2 & 31.46 & 1.16 \\
\hline $\begin{array}{l}\text { Plate }(\text { Depth }) \\
=\text { Error } \mathrm{A}\end{array}$ & 26 & 137.45 & & 20 & 28.52 & & 20 & 27.02 & \\
\hline Surface & 1 & 3164.22 & $27.46^{c}$ & 1 & 42.54 & 1.27 & 1 & 15.43 & 0.57 \\
\hline Depth $\times$ Surface & 2 & 853.82 & $7.41^{\mathrm{C}}$ & 2 & 192.81 & $5.75^{\mathrm{b}}$ & 2 & 85.44 & 3.16 \\
\hline $\begin{array}{l}\text { Surface } \times \text { Plate (Depth) } \\
=\text { Error B }\end{array}$ & 26 & 115.24 & & 20 & 33.54 & & 20 & 27.06 & \\
\hline
\end{tabular}


Table 2. ANOVA of Platygyra daedalea survival from zero to $3 \mathrm{mo}$, zero to $6 \mathrm{mo}$, and zero to 12 mo at North East Reef. (Probability of significant $F<0.05^{\mathrm{a}} ;<0.01^{\mathrm{b}} ;<0.001^{\mathrm{c}}$ )

\begin{tabular}{|c|c|c|c|c|c|c|c|c|c|}
\hline Source of variation & $\mathrm{df}$ & $\begin{array}{c}0-3 \text { mo } \\
\text { MS }\end{array}$ & $F$ & df & $\begin{array}{l}0-6 \mathrm{mo} \\
\mathrm{MS}\end{array}$ & $F$ & $\mathrm{df}$ & $\begin{array}{c}0-12 \mathrm{mo} \\
\mathrm{MS}\end{array}$ & $F$ \\
\hline Depth & 2 & 273.48 & \multirow[t]{2}{*}{$3.62^{a}$} & 2 & 16.33 & \multirow[t]{2}{*}{0.45} & 2 & 1.57 & \multirow[t]{2}{*}{0.12} \\
\hline $\begin{array}{l}\text { Plate (Depth) } \\
=\text { Error } \mathrm{A}\end{array}$ & 17 & 75.56 & & 17 & 36.25 & & 17 & 13.62 & \\
\hline Surface & 1 & 475.86 & \multirow{3}{*}{$\begin{array}{l}10.10^{c} \\
12.27^{c}\end{array}$} & 1 & 90.78 & 3.88 & 1 & 817.88 & 2.08 \\
\hline Depth $\times$ Surface & 2 & 578.43 & & 2 & 106.94 & \multirow{2}{*}{$4.57^{\mathrm{a}}$} & 2 & 26.96 & \multirow[t]{2}{*}{3.14} \\
\hline $\begin{array}{l}\text { Surface } \times \text { Plate }(\text { Depth }) \\
=\text { Error } \mathrm{B}\end{array}$ & 17 & 47.12 & & 17 & 23.37 & & 17 & 8.58 & \\
\hline
\end{tabular}

plates than on the exposed top surfaces of plates, whereas the reverse pattern was found on plates at the lower slope (Fig. 4). The patterns shown by $P$. daedalea follow the same trend as observed for $G$. aspera (Fig. 5). After $12 \mathrm{mo}$, the interaction between depth and plate surface was no longer statistically significant for both species (Tables $1 \& 2$ ), although the trend was consistent with the pattern present during the 3 and 6 mo census (Figs. $4 \& 5$ ).

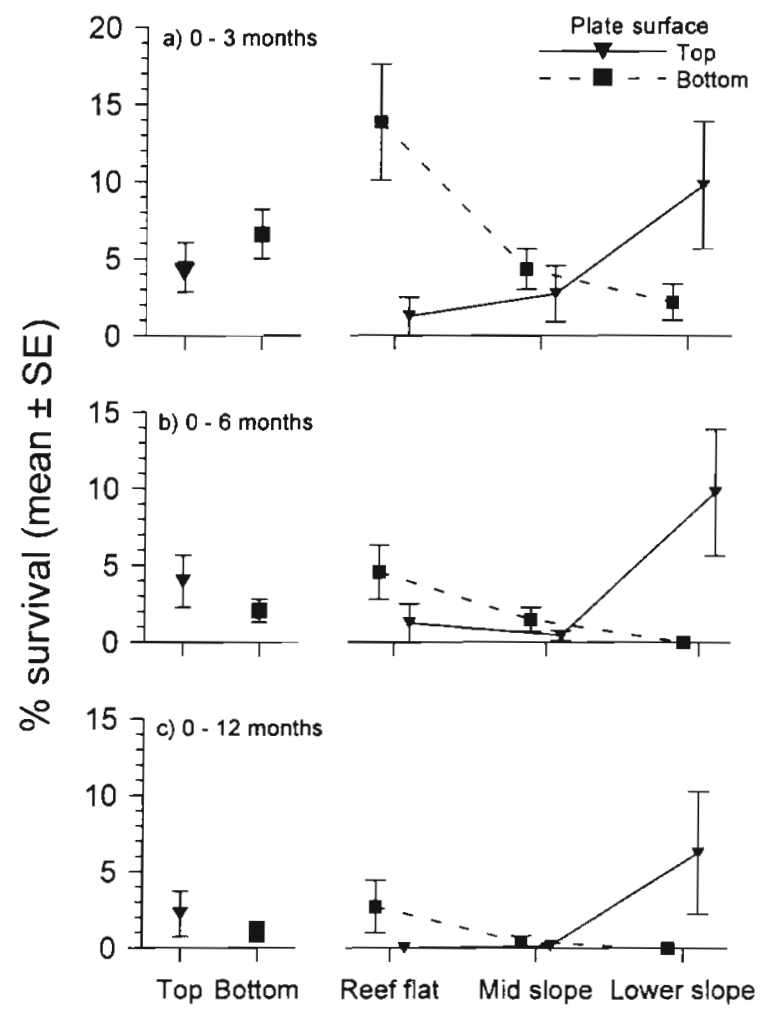

Fig. 4. Mean percent survival of laboratory settled juvenile Goniastrea aspera on plate surfaces at NER from (a) 0 to $3 \mathrm{mo}$, (b) 0 to $6 \mathrm{mo}$, (c) 0 to $12 \mathrm{mo}$. Left panels show \% survival on upper and lower plate surfaces (depths pooled), and right paels show \% survival on top and bottom plate surfaces at each depth
In contrast to the 2 Faviid species, survival of laboratory settled juvenile Oxypora lacera at NER was significantly higher on the bottom surfaces of plates, and there was no siginificant difference in juvenile survival among depths. Additionally, there was no significant interaction between depth and plate surface in this

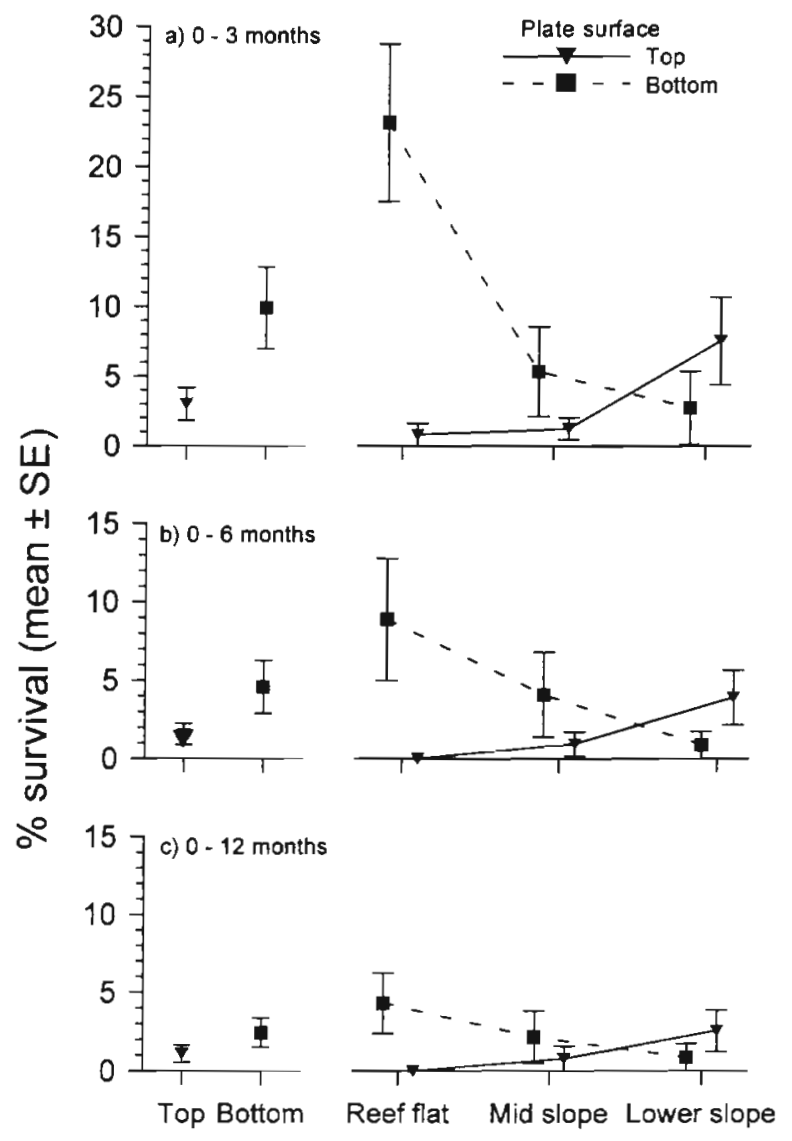

Fig. 5. Mean percent survival of laboratory settled juvenile Platygyra daedalea on plate surfaces at NER from (a) 0 to $3 \mathrm{mo}$, (b) 0 to $6 \mathrm{mo}$, (c) 0 to $12 \mathrm{mo}$. Left panels show \% survival on upper and lower plate surfaces (depths pooled), and right panels show \% survival on top and bottom plate surfaces at each depth 
Table 3. ANOVA of Oxypora lacera survival from zero to 3 mo, zero to 6 mo, and zero to 12 mo at North East Reef. (Probability of significant $F<0.05^{\tilde{a}}$ i $<0.01^{\mathrm{b}} ;<0.001^{\mathrm{c}}$ )

\begin{tabular}{|c|c|c|c|c|c|c|c|c|c|}
\hline \multirow[t]{2}{*}{ Source of variation } & \multicolumn{3}{|c|}{$0-3 \mathrm{mo}$} & \multicolumn{3}{|c|}{$0-6 \mathrm{mo}$} & \multicolumn{3}{|c|}{$0-12$ mo } \\
\hline & df & MS & $F$ & $\mathrm{df}$ & MS & $F$ & $\mathrm{df}$ & MS & $F$ \\
\hline Depth & 2 & 9.24 & 0.04 & 2 & 39.3 & 0.76 & 2 & 8.96 & 0.54 \\
\hline $\begin{array}{l}\text { Plate (Depth) } \\
=\text { Error } \mathrm{A}\end{array}$ & 31 & 211.72 & & 29 & 51.58 & & 29 & 16.61 & \\
\hline Surface & 1 & 3735.44 & $22.77^{c}$ & 1 & 594.36 & $16.03^{c}$ & 1 & 120.7 & $7.66^{b}$ \\
\hline Depth $\times$ Surface & 2 & 195.57 & 1.19 & 2 & 84.69 & 2.28 & 2 & 14.16 & 0.9 \\
\hline $\begin{array}{l}\text { Surface } \times \text { Plate (Depth) } \\
=\text { Error B }\end{array}$ & 31 & & & 29 & 37.07 & & 29 & 15.76 & \\
\hline
\end{tabular}

species (Table 3, Fig. 6). After 3 mo, survival of juvenile O. lacera on protected bottom plate surfaces was more than 5 times $(17.31 \%)$ higher than on exposed top surfaces of plates $(2.45 \%)$. After $12 \mathrm{mo}$, this pattern was broadly similar with $3.19 \%$ of laboratory-settled juvenile $O$. lacera on protected bottom plate surfaces alive, compared to only $0.45 \%$ on the exposed top surfaces of plates (Fig. 6). At the turbid $G B$ site, the patterns

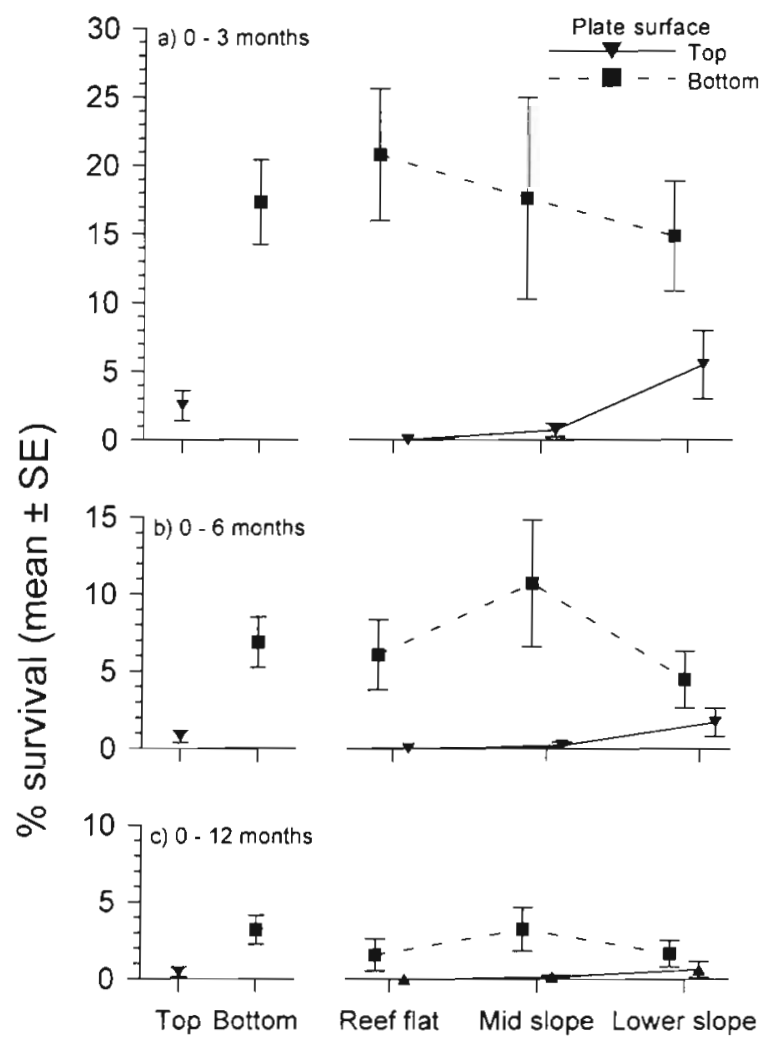

Fig. 6. Mean percent survival of laboratory settled juvenile Oxypora lacera on plate surfaces at NER from (a) 0 to 3 mo, (b) 0 to $6 \mathrm{mo}$, (c) 0 to $12 \mathrm{mo}$. Left panels show \% survival on upper and lower plate surfaces (depths pooled), and right panels show \% survival on top and bottom plate surfaces at each depth
Table 4. ANOVA of Oxypora lacera survivorship of from zero to 3 mo at Geoffrey Bay. (Probability of significant $F<0.05^{\mathrm{a}}$; $<0.01^{\mathrm{b}} ;<0.001^{\mathrm{c}}$; ns: not significant)

\begin{tabular}{lrcc|} 
Source of variation & \multicolumn{3}{c}{$0-3$ mo } \\
\cline { 1 - 2 } & df & MS & $F$ \\
\hline Depth & 1 & 0.01 & $0.00 \mathrm{~ns}$ \\
Plate (Depth) & 18 & 247.1 & \\
= Error A & & & \\
Surface & 1 & 6219.4 & $27.34^{\mathrm{d}}$ \\
Depth $\times$ Surface & 1 & 2575 & $11.32^{\mathrm{b}}$ \\
Surface $\times$ Plate (Depth) & 18 & 227.52 & \\
$=$ Error B & & & \\
\hline
\end{tabular}

differed slightly, with survival of $O$. lacera dependent on depth and plate surface (Table 4, Fig. 7). This was due to a similar shift in survival with depth to that observed for the 2 Faviid species, with an increase in survival on exposed top plate surfaces with increasing depth and a corresponding decrease in survival on
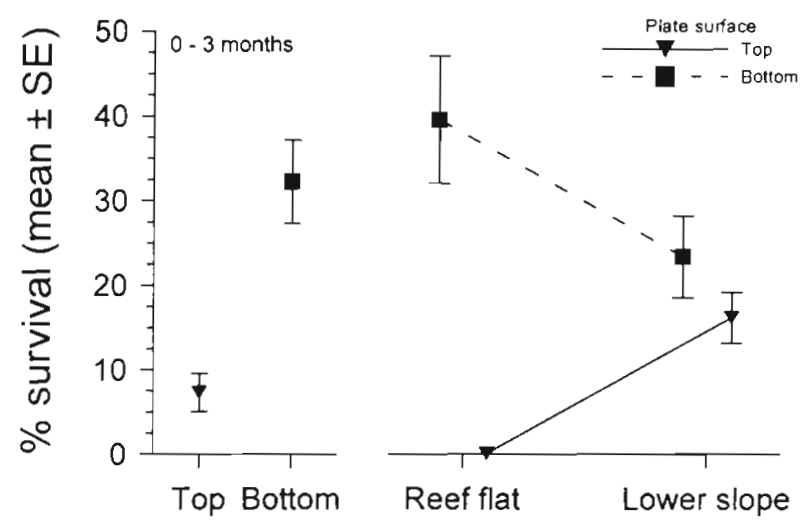

Fig. 7 Mean percent survival of laboratory settled juvenile Oxypora lacera on plate surfaces at Geoffrey Bay (GB) from 0 to 3 mo. Left panels show \% survival on upper and lower plate surfaces (depths pooled), and right panels show \% survival on top and bottom plate surfaces at each depth 
Table 5. Pearson's correlation coefficients for relationship between number of settled juveniles and subsequent survival (depths pooled). Probability of significant $F<0.05^{\mathrm{a}} ;<0.01^{\mathrm{b}} ;<0.001^{\mathrm{c}}$. Numbers in parentheses are sample sizes

\begin{tabular}{|c|c|c|c|c|c|c|}
\hline & \multicolumn{2}{|c|}{ Goniastrea aspera } & \multicolumn{2}{|c|}{ Platygyra daedalea } & \multicolumn{2}{|c|}{ Oxypora lacera } \\
\hline & Upper & Lower & Upper & Lower & Upper & Lower \\
\hline Initial settlers vs $\%$ survival to $3 \mathrm{mo}$ & $\begin{array}{r}-0.35 \\
(26)\end{array}$ & $\begin{array}{l}0.10 \\
(26)\end{array}$ & $\begin{array}{r}-0.20 \\
(20)\end{array}$ & $\begin{array}{l}0.00 \\
(20)\end{array}$ & $\begin{array}{r}-0.02 \\
(34)\end{array}$ & $\begin{array}{r}-0.05 \\
(34)\end{array}$ \\
\hline Survivors at 3 mo vs survivors at 6 mo & $\begin{array}{l}0.81^{\mathrm{c}} \\
(23)\end{array}$ & $\begin{array}{l}0.94^{c} \\
(23)\end{array}$ & $\begin{array}{l}0.83^{c} \\
(20)\end{array}$ & $\begin{array}{l}0.69^{c} \\
(20)\end{array}$ & $\begin{array}{l}0.96^{c} \\
(33)\end{array}$ & $\begin{array}{l}0.96^{c} \\
(33)\end{array}$ \\
\hline Survivors at 6 mo vs survivors at 12 mo & $\begin{array}{l}0.85^{c} \\
(23)\end{array}$ & $\begin{array}{l}0.79^{c} \\
(23)\end{array}$ & $\begin{array}{l}0.98^{c} \\
(20)\end{array}$ & $\begin{array}{l}0.90^{c} \\
(20)\end{array}$ & $\begin{array}{l}0.88^{\mathrm{c}} \\
(33)\end{array}$ & $\begin{array}{l}0.97^{\mathrm{c}} \\
(33)\end{array}$ \\
\hline
\end{tabular}

protected bottom plate surfaces (Figs. $4,5 \& 7$ ). At GB, survival of laboratory-settled juvenile $O$. lacera on the top surfaces of plates at the lower slope site after 3 mo was relatively high, with only marginally lower survival on the top surface $(16.1 \%)$ than on the bottom surface $(23.3 \%$ ) (Fig. 7). The trend in survival of O. lacera at GB among depths and plate surfaces after 3 mo was comparable to that observed at NER (Figs. 6 \& 7).

No relationship was found between the density of corals at the beginning of the experiment $(9 \mathrm{~d})$ and the probability of survival to 3 mo (Table 5) (depths pooled). Additionally, a strong positive relationship was found between the number of laboratory-settled juveniles on top and bottom plate surfaces at $3 \mathrm{mo}$ and the number of laboratory-settled juveniles present at 6 mo for all 3 species (Table 5) (depths pooled). A strong positive relationship was also found between the number of survivors present at 6 mo and the number of survivors at $12 \mathrm{mo}$ (depths pooled). These results are consistent with those expected under conditions of density-independent mortality.

Planned statistical comparisons of size attained by juveniles among depths and plate surfaces using ANOVA models were not possible due to the unbal- anced nature of the dataset resulting from the poor survival of juveniles on the top surfaces of plates at the reef flat and on the bottom plate surfaces at the lower slope site. The mean size attained by all 3 species after 12 mo was relatively small (Fig. 8). Surprisingly, over the 12 mo period, Goniastrea aspera juveniles on the exposed top surfaces of plates located at the lower slope site attained the largest mean diameter $(3.96 \mathrm{~mm})$ (Fig. 8). In comparison, the mean diameter of Oxypora lacera juveniles placed under the same conditions was only $1.03 \mathrm{~mm}$ (Fig. 8).

\section{DISCUSSION}

The patterns of early post-settlement survival of Goniastrea aspera and Oxypora lacera with depth in this study do not support a model of indiscriminate settlement followed by differential post-settlement mortality with depth as a mechanism maintaining depth distributions in these species. The results do, however, provide support for the alternative mechanism, that zonation is set and maintained by depth-dependent settlement. Laboratory-settled $G$. aspera and O. lacera

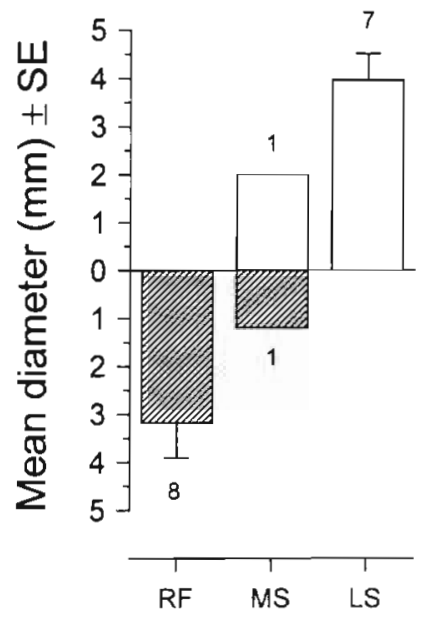

Goniastrea aspera

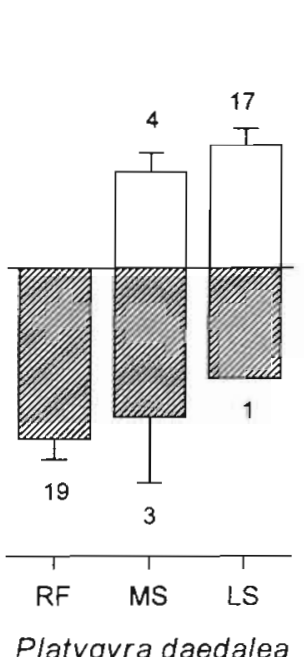

Platygyra daedalea

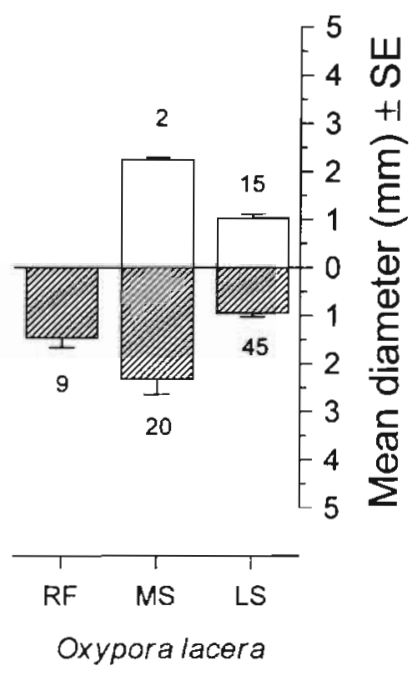

Fig. 8. Mean diameter $(\mathrm{mm})$ of laboratory settled juveniles after 12 mo. Open bars indicate mean diameter of corals on the exposed top plate surface, and shaded bars indicate mean diameter of corals on the protected lower plate surface 
juveniles survived for 12 mo at depths well outside the normal depth range of each species, and at rates comparable to survival of juveniles placed within the normal depth range (Figs. 1 to 3 ). These patterns are consistent with results reported by us for Platygyra sinensis and $O$. lacera in an earlier study (Babcock \& Mundy 1996). The size attained by $G$. aspera and $O$. lacera juveniles placed outside the normal depth range was also comparable to the size of juveniles placed within the normal depth range of these 2 species (Fig. 8). Survival of $P$. daedalea juveniles was also sim. ilar among depths which, in contrast to $G$. aspera and $O$. lacera, is consistent with the broad depth distribution of $P$. daedalea on NER and nearby reefs (Miller 1994).

The results of this study for Goniastrea aspera and Oxypora lacera, in combination with the ability of larvae of these species to distinguish between light regimes characteristic of shallow and deep reef habitats at settlement (Mundy \& Babcock 1998), suggest that vertical zonation of these species is set and maintained by depth-dependent settlement. This interpretation is only valid, however, if we assume that differential survival with depth of $G$. aspera and $O$. lacera would not have occurred at an age later than examined in this study, but prior to an age where they can be reliably identified in the field (e.g. between 12 and $36 \mathrm{mo}$ ). Depth-dependent mortality of older juveniles seems unlikely given the low numbers of unidentifiable, but visible recruits on reefs. If mortality at later life-history stages were a general phenomenon leading to zonation, we would expect large numbers of unidentifiable juvenile corals to be present. Also, in the Caribbean (where taxonomic identification is much less of a problem due to lower diversity) there has been no indication of such a pattern (Bak \& Engel 1979, Rogers et al. 1984). If differential survival with depth does occur during this later period (not examined here), this would be a significant departure from the notion that the early post-settlement period of sessile invertebrates is the most precarious life-history stage (Chia 1989). Additionally, it would imply that recently settled juveniles are more robust to factors limiting species depth distributions than older, established individuals.

The continued survival of laboratory-settled Goniastrea aspera and Oxypora lacera juveniles at depths outside their normal range are comparable to results of several studies involving transplants of individuals outside their normal depth range. Transplanted adults of 4 gorgonian species survived for $2 \mathrm{yr}$ at depths where adult colonies were not normally found (Weinberg 1979a). Response of larvae to light by 2 of these gorgonian species was, however, consistent with the depth distribution of adults (Weinberg 1979b) (as found for $G$. aspera and O. lacera; Mundy \& Babcock
1998). Transplants of the lower-slope (15 to $20 \mathrm{~m}$ ) phototrophic sponge Cymbastela concentrica to $5 \mathrm{~m}$ survived for 4 mo with no evidence of detrimental effects (Seddon et al. 1992). Additionally, tadpole larvae of the ascidian Diplosoma similis preferentially swim and settle to the upper slope where adult abundance is greatest (Stoner 1992). Nonetheless D. similis also settle, survive and successfully reproduce at greater depths (Stoner 1992). However, the results of this study differ from several studies of early post-settlement mortality of marine invertebrates, where recently settled juveniles did not survive in areas where adults are largely absent (e.g. Denley \& Underwood 1979, Keough \& Downes 1982, Young \& Chia 1984, Raimondi 1988, Dalby \& Young 1992, Hunt \& Scheibling 1997).

One possible explanation for the absence of differential survivorship with depth of Goniastrea aspera and Oxypora lacera during this study is that factors affecting survival with depth may occur as discrete, periodic events rather than continuous, chronic effects (Bak \& Engel 1979), and did not occur during the time frame of this study. Periodic disturbances affecting shallow reef habitats include tropical storms and cyclones, extreme temperatures (Glynn et al. 1993), exposure to air (Fadlallah et al. 1995), and reduced salinity after intense rainfall. These sources of coral mortality are likely to set the upper depth limit for some coral species (Sheppard 1982), and explain the absence of lower slope species such as 0 . lacera on reef flats. However, the effects of many of these factors diminish rapidly with depth, and are unlikely to explain the absence of species such as $O$. lacera from upper and mid reef slopes, or the absence of $G$. aspera from mid and lower reef slope areas. For example, the occasional exposure of reef flat corals to air (which occurred between 3 and 6 mo after settlement in this study) may prevent $O$. lacera from establishing on the reef flat. However, the effect of exposure at the study site was restricted to the reef flat site and the impact varied depending upon small-scale differences in elevation $(10$ to $20 \mathrm{~cm})$ of replicate plates.

The ability of corals to tolerate UV light may also be a determinant of the upper depth limits of some coral species. Vareschi \& Fricke (1986) found that the lower slope species Plerogyra sinuosa died when transplanted to shallow habitats unless protected by UV blocking perspex sheets. Differing concentrations of a broad spectrum UV blocking compound found in brown and green colour morphs of Porites asteroides have also been correlated with different depth distributions of the 2 morphs (Gleason 1993). Oxypora lacera juveniles surviving to 12 mo on the reef flat and mid slope at Orpheus Island in this study were predominantly on bottom plate surfaces. Their protection from direct exposure to UV light is one possible explanation 
for the survival of $O$. lacera juveniles at these shallow depths.

In contrast to Oxypora lacera, no plausible explanation could be found for the high survivorship of laboratory-settled juveniles of the reef flat coral Goniastrea aspera at the mid and lower slope sites, where adults of this species are rare or absent respectively. The surviving G. aspera juveniles at the lower slope site were present entirely on upper plate surfaces, and would have been exposed to the same conditions as those experienced by established corals (e.g. low light, high sedimentation). Thus $G$. aspera was capable of adapting physiologically to the low light conditions typical of deeper habitats, and demonstrates that G. aspera would survive at the lower slope at NER if planulae happened to settle there. This leads to the obvious question of why G. aspera is not found at the lower slope of NER (or other nearby reefs)?

Mortality of recently settled juveniles after placement in (or settlement in) locations outside of their natural depth range is the response usually considered as a priori evidence for selective pressure underlying adaptive larval behaviour (e.g. Denley \& Underwood 1979, Young \& Chia 1984). The expected result from this experiment was that all laboratory-settled Goniastrea aspera and Oxypora lacera juveniles placed outside the normal depth range of these species would die within a short period (within $3 \mathrm{mo}$ ), whereas laboratorysettled Platygyra daedalea juveniles would survive at all depths examined. Indeed, the shift in survival of $P$. daedalea juveniles from lower plate surfaces to upper plate surfaces with increasing depth matches the shift in settlement orientation of this species in response to decreasing light (Mundy \& Babcock 1998, their Fig. 9). Thus the choice of settlement orientation (exposed vs cryptic) in response to light cues by $P$. daedalea larvae appears to be an adaptive behaviour that would maximise early post-settlement survival. In contrast, the continued survival of the 2 zone-specific species $G$. aspera and $O$. lacera at all depths does not provide evidence of selective pressure for the apparently adaptive settlement behaviours reported from these species in our earlier study (Mundy \& Babcock 1998).

An alternative to whole colony mortality as selective pressure for larval behaviour is that individuals establishing in sub-optimal depths or habitats may have a lower fitness relative to individuais that establish within an optimal depth range. If the differences in fitness were large, this could apply sufficient selective pressure for adaptive larval behaviour, and may explain the survival of laboratory-settled juveniles outside the normal depth range of established populations in this study. Some support for reduced fitness as a selective pressure for larval behaviour can be found in aspects of general coral reproductive biology. Fecun- dity of Acropora palifera appears to decrease with increasing depth (Kojis \& Quinn 1984), and fecundity of $A$. formosa appears to increase with increasing depth (Harrison \& Wallace 1990). Observations of relatively fewer reproductive colonies and lower fecundity of the gorgonians Muricea californica and $M$. fruticosa at the lower limit of their depth range in California (Grigg 1979) provides further support for this hypothesis. Slower growth rates of corals at some depths have been observed in the Caribbean coral Montastrea annularis (Wyman et al. 1987, Bosscher \& Meesters 1993) and may influence fitness (and survival) over relatively longer time scales. Additionally, in a study of several Caribbean coral species, Wyman et al. (1987) suggested that in some species there might be a photosynthetic optimum depth.

The results from this study allow future research on mechanisms underlying vertical zonation to be more tightly focused. Specific hypotheses that require testing are (1) that survival of zone-specific species between 12 and 36 mo post-settlement is independent of depth and (2) that fitness of zone-specific corals is significantly reduced at depths outside their normal depth range. Although planulae of Goniastrea aspera and Oxypora lacera are capable of detecting a suitable cue (light quality/intensity) for locating shallow or deep water habitats (Mundy \& Babcock 1998), it is not yet clear whether the planulae are able to influence their position in the water column in response to such cues. Thus further investigations on the response of larvae to environmental or biological cues prior to or at settlement, and the consequences of such behaviours for species distributions, are also a priority for future work.

Acknowledgements. This is contribution number 1002 from the Australian Institute of Marine Science. This research was supported by an Australian Institute of Marine Science Postgraduate Research Award, the Zoology Department, University of Queensland, and a Great Barner Reef Marine Park Authority Augmentative Grant. We would also like to thank Karen Miller and 3 anonymous reviewers for their comments on an earlier draft of this manuscript, and Craig Johnson for encouragement, support and statistical advice. K. Miller and Ulrike Siebeck provided invaluable assistance with field and laboratory aspects of this study.

\section{LITERATURE CITED}

Babcock RC (1984) Reproduction and distribution of two species of Goniastrea (Scleractinia) from the Great Barrier Reef Province. Coral Reefs 2:187-195

Babcock RC (1985) Growth and mortality in juvenile corals (Goniastrea, Platygyra and Acropora): the first year. Proc 5th Int Coral Reef Symp Tahiti 4:355--359

Babcock RC (1991) Comparative demography of three species of scleractinian corals using age- and size-dependent classifications. Ecol Monogr 61:225-244 
Babcock RC, Heyward A.J (1986) Larval development of certain gamete-spawning scleractinian corals. Coral Reefs 5: $111-116$

Babcock RC, Mundy CN (1996) Coral recruitment: consequences of settlement choice for early growth and survivorship in two scleractinians. J Exp Mar Biol Ecol 206: $179-201$

Bak RPM, Engel MS (1979) Distribution, abundance and survival of juvenile hermatypic corals (Scleractinia) and the importance of life history strategies in the parent coral community. Mar Biol 54:341-352

Bosscher H, Meesters EH (1993) Depth related changes in the growth rate of Montastrea annularis. Proc 7th Int Caral Reef Symp Guam 1:507-512

Chadwick NE (1991) Spatial distribution and the effects of competition on some temperate Scleractinia and Corallimorpharia. Mar Ecol Prog Ser 70:39-48

Chia FS (1989) Differential larval settlement of benthic marine invertebrates. In: Ryland JS, Tyler PA (eds) Reproduction, genetics and distributions of marine organisms. European Marine Biology Symposium, Swansea, p 3-12

Colgan MW (1987) Coral reef recovery on Guam (Micronesia) after catastrophic predation by Acanthaster planci. Ecology 68:1592-1605

Dalby JEJ, Young CM (1992) Role of early post-settlement mortality in setting the upper depth limit of ascidians in Florida epifaunal communities. Mar Ecol Prog Ser 80. 221-226

Denley EJ, Underwood AJ (1979) Experiments on factors influencing settlement, survival, and growth of two species of barnacles in New South Wales. J Exp Mar Biol Ecol 36:269-293

Done TJ (1982) Patterns in the distribution of coral communities across the central Great Barrier Reef. Coral Reefs 1 95-107

Doyle RW (1974) Choosing between darkness and light: the ecological genetics of photic behaviour in the planktonic larva of Spirorbis borealis. Mar Biol 25:311-317

Fadlallah YH, Allen KW, Estudillo RA (1995) Mortality of shallow reef corals in the western Arabian Gulf following aerial exposure in winter. Coral Reefs 14:99-107

Gleason DF (1993) Differential effects of ultraviolet radiation on green and brown morphs of the Caribbean coral $P_{\text {orites }}$ astreoides. Limnol Oceanogr 38:1452-1463

Glynn PW (1976) Some physical and biological determinants of coral community structure in the eastern Pacific. Ecol Monogr 46:431-456

Glynn PW, Imai R, Sakai K, Nakano Y, Yamazato K (1993) Experimental responses of Okinawan (Ryukyu Islands, Japan) reef corals to high sea temperatures and UV radiation. Proc 7 th Int Coral Reef Symp Guam 1:27-37

Grigg RW (1979) Reproductive ecology of two species of gorgonian corals: relations to vertical and geographical distribution. In: Stancyk SE (ed) Reproductive ecology of marine invertebrates. University of South Carolina Press, Columbia, p 41-59

Grosberg RK (1982) Intertidal zonation of barnacles: the influence of planktonic zonation of larvae on vertical distribution of adults. Ecology 63:894-899

Harrison PL, Wallace CC (1990) Reproduction, dispersal and recruitment of scleractinian corals. In: Dubinsky $Z$ (ed) Ecosystems of the world 25. Coral reefs. Elsevier, Amsterdam, p 133-207

Hunt HL, Scheibling RE (1997) Role of early post-settlement mortality in recruitment of benthic marine invertebrates. Mar Ecol Prog Ser 155:269-301
Huston MA (1985) Patterns of species diversity on coral reefs Annu Rev Ecol Syst 16:149-177

Keough MJ, Downes BJ (1982) Recruitment of marine invertebrates: the role of active larval choices and early mortality. Oecologia 54:348-352

Kojis BL, Quinn NJ (1984) Seasonal and depth variation in fecundity of Acropora palifera at two reefs in Papua New Guinea. Coral Reefs 3:165-172

Larcombe P, Ridd PV, Prytz A, Wilson B (1995) Factors controlling suspended sediment on inner-shelf coral reefs, Townsville, Australia. Coral Reefs 14:163-171

Miller KJ (1994) Morphological variation in the genus Platygyra: environmental influences and taxonomic implications. Mar Ecol Prog Ser 110:19-28

Morse DE, Hooker N, Morse ANC, Jensen RA (1988) Control of larval metamorphosis and recruitment in sympatric Agariciud corals. J Exp Mar Biol Ecol 116:193-217

Mundy CN (2000) A new method for the attachment of artificial settlement plates to the reef substratum to measure coral recruitment. Coral Reefs 19 (in press)

Mundy CN, Babcock RC (1998) Role of light intensity and spectral quality in coral settlement: implications for depth-dependent settlement? J Exp Mar Biol Ecol 223: 235-255

Raimondi PT (1988) Settlement cues and determination of the vertical limit of an intertidal barnacle. Ecology 69:400-407

Rogers CS, Fitz HC III, Gilnack M, Beets J, Hardin J (1984) Scleractinian coral recruitment patterns at Salt River Submarine Canyon, St. Croix, US Virgin Islands. Coral Reefs 3:69-76

Sebens KP, Done TJ (1992) Water flow, growth form and distribution of scleractinian corals: Davies Reef (GBR), Australia. Proc 7 th Int Coral Reef Symp Guam 1:557-568

Seddon S, Cheshire AC, Wilkinson CR (1992) Photophysiology and acclimation of the coral reef sponge Cymbastela concentrica across a depth gradient. Proc 7 th Int Coral Reef Symp Guam 2:847-852

Sheppard CRC (1982) Coral populations on reef slopes and their major controls. Mar Ecol Prog Ser 7:83-115

Stoner DS (1992) Vertical distribution of a colonial ascidian on a coral reef: the roles of larval dispersal and ife-history variation. Am Nat 139:802-824

Vareschi E, Fricke H (1986) Light responses of a scleractinian coral Plerogyra sinuosa. Mar Biol 90:395-402

Veron JEN, Pichon M (1980) Scleractinia of eastern Australia: Part III. Australian Institute of Marine Science and Australian National University Press, Canberra, p 1-422

Wallace CC, Bull GD (1981) Patterns of juvenile coral recruitment on a reef front during a spring-summer spawning period. Proc 4 th Int Coral Reef Symp Manila 2:345-350

Weinberg S (1979a) Transplantation experiments with Mediterranean Gorgonians. Bijdr Dierkd 49:31-41

Weinberg S (1979b) The light-dependent behaviour of planula larvae of Eunicella singularis and Corallium rubrum and its implication for Octocorallian ecology. Bijdr Dierkd 49:16-30

Winer BJ, Brown DR. Michels KM (1991) Statistical principles in experimental design, 3rd edn. McGraw-Hill, New York

Wyman KD, Dubinsky Z, Porter JW, Falkowski PG (1987) Light absorption and utilization among hermatypic corals: a study in Jamaica, West Indies. Mar Biol 96:283-292

Young CM, Chia FS (1984) Microhabitat-associated variability in survival and growth of subtidal solitary ascidians during the first 21 days after settlement. Mar Biol 81: $61-68$ 